\title{
Radioimmunoassay that measures serum vitamin B12
}

J J O'Sullivan, R J Leeming, S S Lynch, A Pollock

\begin{abstract}
Aims: To develop a specific radioimmunoassay for the routine determination of serum vitamin $B 12$.

Methods: Antisera were raised in rabbits by immunisation with the monocarboxylic acid derivative of cyanocobalamin coupled to human serum albumin. Antibody titres and affinities were determined and the antiserum giving the highest binding affinity constant, $\mathrm{Ka}$, was used to develop the assay protocol. Donkey-anti-rabbit gamma globulin-coated magnetisable particles were used to separate the bound from free vitamin B12. The considerable cobalamin binding capacity of human serum was destroyed by autoclaving in acetate-cyanide buffer. Sixty samples were assayed by the radioimmunoassay (RIA) and the Lactobacillus leichmannii assay. Recovery and cross-reactivity experiments were performed.
\end{abstract}

Results: Final rabbit antibody titres varied from $1 / 20000$ to $1 / 188000$. Scatchard plots did not correlate with the antibody titres. The $\mathrm{Ka}$ values varied from 2.6 to $6.7 \times 10^{10}$ litres $/ \mathrm{mol}$. For maximum sensitivity the highest $\mathrm{Ka}$ (titre 1/66 000) was chosen. A tracer concentration of $22 \mathrm{pmol} / 1$, an antiserum dilution of $1 / 100000$, and a sample volume of $0.1 \mathrm{ml}$ were used. At an antiserum dilution of 1 in 100000 the cyanocobalamin binding of the rabbit serum was diluted out. The assay showed excellent correlation with the microbiological assay, with $100 \%$ recovery of added vitamin B12. Levels of cross-reactivity for dicyanide cobinamide and hydroxocobalamin were $\mathbf{9 . 8}$ and $8 \cdot 1 \%$, respectively.

Conclusions: The development of this immunoassay permits the measurement of serum vitamin $B 12$ without important interference from cobalamin analogues, related corrinoids, and non-specific binders.

The first in vitro measurements of vitamin B12 in serum were by microbiological assays, developed in the 1950s and based on the requirements of certain organisms for corrinoids as growth factors. ${ }^{1-10}$ Although sensitive, cheap, and simple in concept, accurate and reproducible results require care and experience. The disadvantages include long incubation times, possible microbial contamination, and suppression of growth by antibiotics and cytotoxic drugs. ${ }^{11}$ Over the past 25 years microbiological assays have been replaced in most laboratories by radioisotope dilution assays (RIDA), using intrinsic factor (IF) and R-protein as binders. In the 1970s RIDAs achieved popularity because of claims that they were technically simpler, more accurate and reproducible than microbiological assays, free from microbial and iatrogenic interference, and commercially available as kits. Several vitamin B12 binders and separation systems have been used. ${ }^{12-21}$

Comparisons of RIDAs with microbiological assays have shown discrepancies attributable to biologically inactive cobalamin analogues. ${ }^{22-24}$ High performance liquid chromatography provides a rapid and reproducible means of characterising physiological cobalamins but is not sufficiently sensitive to detect the concentrations found in human serum. ${ }^{25} 26$

The availability of an immunoassay specific for vitamin B12 and free from interference by cobalamin analogues, related corrinoids, or non-specific binders would be of value for the routine measurement of serum vitamin B12 Although radioimmunoassay methods ${ }^{27-31}$ have been developed, they have not been widely used due to difficulties in preparing appropriate antibodies. We present here details of an immunoassay for the determination of serum vitamin B12 concentrations using antibodies raised in rabbits against the monocarboxylic acid derivative of cyanocobalamin conjugated to human serum albumin.

\section{Methods}

Cyanocobalamin (crystalline, pure; Sigma) was subjected to mild acid hydrolysis with $0.4 \mathrm{M}$ hydrochloric acid (BDH) and the monocarboxylic acid derivative purified on a column $(2.5 \times 56 \mathrm{~cm})$ of QAE-Sephadex A-25 (Pharmacia LKB). The vitamin B12-human serum albumin (HSA, purified, lophilised; Behringwerke AG) conjugate was prepared by a modification of the method of Ahrenstedt and Thorell. ${ }^{32}$ The addition of the spacer molecule into the conjugate was omitted and TRIS buffer (AnalaR, BDH) was used instead of pyridine, followed by desalting on Sephadex G-15 (Pharmacia). The conjugate was then lyophilised, redissolved in deionised water to $1.5 \mathrm{mg}$ / $\mathrm{ml}$ and stored at $-70^{\circ} \mathrm{C}$. Vitamin B12-HSA conjugate, $1.5 \mathrm{mg}$ in $1.0 \mathrm{ml}$ of deionised water, 
was emulsified with $1.0 \mathrm{ml}$ Freund's Complete Adjuvant and injected intradermally, at multiple sites, on the backs of five adult rabbits. Blood samples were collected monthly from the marginal ear vein and the antibody titres were determined. Injections were at monthly intervals over four months.

Four bovine serum albumin (BSA) preparations were evaluated for use in the assay diluent: (i) 98-99\% BSA; (ii) RIA garde BSA; (iii) vitamin $\mathrm{B} 12$ and $\mathrm{B} 12$ binding factor deficient BSA (all from Sigma); and (iv) human plasma protein fraction (Blood Products Laboratory). Diluents contained $0.5 \% \mathrm{w} / \mathrm{v}$ BSA, with and without $0.2 \% \mathrm{v} / \mathrm{v}$ Tween -20 .

Serial dilutions of antiserum were made in $0.05 \mathrm{M}$ phosphate buffered saline (PBS) (pH $7 \cdot 0$ ) containing $0.5 \%$ BSA (98-99\% albumin; Sigma) and $0 \cdot 1 \%$ sodium azide. Each antiserum dilution $(0.35 \mathrm{ml})$ was pipetted in duplicate into polystyrene assay tubes $(75 \times 12 \mathrm{~mm}$ Sarstedt) with $0.05 \mathrm{ml} \mathrm{PBS}$ and $0.1 \mathrm{ml} 44 \mathrm{pmol} / 1$ cyano $\left(\mathrm{Co}^{57}\right)$ cobalamin $(\mathrm{CT} 2$, high specific activity, $370 \mathrm{KBq} / \mathrm{ml}$; Amersham International Ltd.) and incubated at $20^{\circ} \mathrm{C}$ for 16 hours. Magnetisable particles $(0.5 \mathrm{ml}$, $2 \mathrm{~g} / \mathrm{l})$, freshly resuspended and intermittently mixed to avoid settling out, was added to all tubes, except the "total activity" tubes. After mixing thoroughly the tubes were left standing, undisturbed, at $20^{\circ} \mathrm{C}$ for 30 minutes, then placed over a Magnetic Separator (Serono Diagnostics Ltd.) for five minutes. While standing on the magnets the supernatants were aspirated to waste using a Venturi water-jet pump. The pellets of magnetisable particles were resuspended in saline $(1.5 \mathrm{ml})$ and the tubes were again left to stand on the magnets for five minutes. The supernatants were aspirated to waste and the tracer bound to the magnetisable particles was measured using an NE 1600 multiple well-type gamma counter. Included in each assay were two "total activity" tubes, containing only tracer and two "blank" or non-specific binding tubes, containing no antiserum. The titre of each antiserum was expressed as the antiserum dilution which bound $50 \%$ of the cyano $\left(\mathrm{Co}^{57}\right)$ cobalamin tracer added.

The rabbit antisera were diluted in PBS as follows: $\quad R 1=1 / 20000 ; \quad R 2=1 / 95000$; $\mathrm{R} 3=1 / 12500 ; \mathrm{R} 4=1 / 30000 ;$ and $\mathrm{R} 5=$ $1 / 17500$. Antiserum $(0.35 \mathrm{ml})$ was pipetted into each tube. Cyano $\left(\mathrm{Co}^{57}\right)$ cobalamin was diluted in PBS to give final concentrations of $700,350,175,88$ and $44 \mathrm{pmol} / 1$ and $0 \cdot 1 \mathrm{ml}$ was pipetted into tubes to which PBS $(0.05 \mathrm{ml})$ was added and mixed. After incubation at $20^{\circ} \mathrm{C}$ for 16 hours and separation as above Scatchard plots were prepared by plotting the bound:free ratio against total concentration of bound tracer. The slope gave the antibody affinity, $\mathrm{Ka}$, litres/mols.

Rabbit 4 antiserum $(0.35 \mathrm{ml})$ diluted $1 / 100$, $1 / 1000,1 / 5000,1 / 10000,1 / 50000,1 / 100000$

ॠThe gamma globulin fraction of the serum of donkeys immunised against rabbit gamma globulins was coupled to particles of iron oxide (magnetic, precipitated) that had been coated with cellulose. These particles were stored at $4^{\circ} \mathrm{C}$, at about $50 \mathrm{~g} / 1$. For use in the assay, they were diluted to about $2 \mathrm{~g} / 1$ in saline containing hydroxypropylmethyl cellulose (visco solution $4000 \mathrm{cP}$; Sigma) at a concentration of $3 \mathrm{~g} / \mathrm{l}$. and $1 / 500000$ in PBS was pipetted into tubes. Cyano $\left(\mathrm{Co}^{57}\right)$ cobalamin was diluted in PBS to give concentrations of $176,88,44,22$ and $11 \mathrm{pmol} / 1$. Tracer $(0.1 \mathrm{ml})$ and PBS $(0.05 \mathrm{ml})$ were added. The tubes were mixed and incubated at $20^{\circ} \mathrm{C}$ for 16 hours before separation and antiserum dilution curves drawn.

Cyanocobalamin solution (Cytamen injection BP, $1000 \mathrm{mg} / \mathrm{l}$; Glaxo) was diluted to give concentrations of $0,15,37,74,185,369,553$ and $738 \mathrm{pmol} / 1$ and $0.1 \mathrm{ml}$ pipetted into tubes followed by $\mathrm{R} 4$ antiserum $(0.3 \mathrm{ml}, 1 / 100000)$. The tubes were mixed and incubated at $20^{\circ} \mathrm{C}$ in the dark for three hours. Then cyano$\left(\mathrm{Co}^{57}\right)$ cobalamin $\quad(0.1 \mathrm{ml}, 22 \mathrm{pmol} / \mathrm{l})$ was added. After mixing, the tubes were incubated at $20^{\circ} \mathrm{C}$ in the dark for 16 hours before separation. The percentage tracer bound was calculated as $\mathrm{B} / \mathrm{Bo}$, where $\mathrm{B}$ is the percentage tracer bound and $B o$ is the percentage of tracer bound by the zero standard.

Normal human serum and non-immune rabbit serum were diluted $1 / 10,1 / 100,1 / 1000$ and $1 / 10000$ in PBS. Each dilution $(0.35 \mathrm{ml})$, cyano $\left(\mathrm{Co}^{57}\right)$ cobalamin $(0.1 \mathrm{ml}, 22 \mathrm{pmol} / \mathrm{l})$, and PBS $(0.05 \mathrm{ml})$ were pipetted into tubes which were incubated at $20^{\circ} \mathrm{C}$ for 16 hours then separated with BSA-coated charcoal in PBS.

To release vitamin $\mathrm{B} 12$ and to destroy vitamin B12 binders sera were diluted 1 in 3 for RIA and 1 in 10 for microbiological assay (Lactobacillus leichmannii) with $0.02 \mathrm{M}$ acetate-cyanide buffer, $\mathrm{pH} 4 \cdot 5$. The tubes were sealed and autoclaved at $121^{\circ} \mathrm{C}$ for five minutes. After cooling and centrifuging at $1750 \times g$ for 10 minutes supernatants $(0.1 \mathrm{ml})$ were assayed.

For recovery of exogenous vitamin B12, cyanocobalamin (74, 148, 295 and $590 \mathrm{pmol} / \mathrm{l}$ ) was added to human serum prior to the extraction procedure and the recovery determined by RIA.

Standard curves were prepared with cyanocobalamin, dicyanide cobinamide, and hydroxocobalamin and the cross-reactivity of each for the antibody binding sites was determined.

\section{Results}

ASSESSMENT OF BSA PREPARATIONS USED IN ASSAY DILUENT

Certain commercially available BSA preparations bound unacceptably high concentrations of vitamin B12 (table 1). Tween-20 is used in several assay diluents. We found Tween-20 in PBS bound cyano $\left(\mathrm{Co}^{57}\right)$ cobalamin (table 1 ). Competition between Tween-20 and antisera decreased assay sensitivity and was omitted.

ANTISERUM TITRATION AND AFFINITY CONSTANT DETERMINATION

R2 produced the best response to the conjugate, giving a final antibody titre of $1 / 188000$ (table 2) and R3 the lowest, 1/20 000. Antibody affinities ranged from $6.7 \times 10^{10} \mathrm{l} / \mathrm{mol}$ for $\mathrm{R} 4$ to $2.6 \times 10^{10} \mathrm{l} / \mathrm{mol}$ for R3 and R5 (table 2), the affinities and titres not being.in the same order. R4 with the highest binding affinity for cyanocobalamin was used for the assay of serum vitamin $\mathrm{B} 12$. The vitamin $\mathrm{B} 12$ conjugate antibody titres (table 2) were lower than those 
Table 1 Assessment of serum albumin preparations for their capacity to bind cyano $\left(\mathrm{Co}^{57}\right)$ cobalamin

\begin{tabular}{llc}
\hline & \multicolumn{2}{l}{ Percentage non-specific binding } \\
\cline { 2 - 3 } PBS buffer & With Tween-20 & Without Tween-20 \\
\hline No albumin & $48 \cdot 2$ & $0 \cdot 4$ \\
BSA (i) & $52 \cdot 3$ & $3 \cdot 0$ \\
BSA (ii) & $55 \cdot 6$ & $52 \cdot 0$ \\
BSA (iii) & $38 \cdot 7$ & $10 \cdot 7$ \\
HPPF (iv) & 47.9 & $3 \cdot 2$ \\
\hline
\end{tabular}

(i) $98-99 \%$ bovine serum albumin

(ii) RIA grade bovine serum albumin

(iii) vitamin $\mathrm{B} 12$ and $\mathrm{B} 12$ binding factor deficient bovine serum albumin.

(iv) human plasma protein fraction

Table 2 Antibody binding affinity constants and antibody titres for each of five rabbits

\begin{tabular}{llc}
\hline & $\begin{array}{l}\text { Antibody affinity } \\
\text { constant }(\text { Ka }) \\
L / N \times 10^{10}\end{array}$ & $\begin{array}{l}\text { Antibody titre } \\
\text { per ml } \times 10^{-3}\end{array}$ \\
\hline Antiserum & $4 \cdot 2$ & 45000 \\
Rabbit 1 & $4 \cdot 5$ & 188000 \\
Rabbit 2 & $2 \cdot 6$ & 20000 \\
Rabbit 3 & $6 \cdot 7$ & 66000 \\
Rabbit 4 & $2 \cdot 6$ & 27000 \\
Rabbit 5 & & \\
\hline
\end{tabular}

of Ahrenstedt and Thorell, ${ }^{32}$ but higher than those of van de Wiel et al. ${ }^{28}$ The antibody binding affinity constants determined by Scatchard analyses showed that antibody affinities did not correlate with antibody titres. R4 antiserum did not have the highest antibody titre but it had the greatest binding affinity for cyanocobalamin (table 2 ).

$\mathrm{R} 4$ antiserum (1/100 000) and a tracer concentration of $22 \mathrm{pmol} / 1$ giving a Bo value of $43 \%$ were used in the development of the assay protocol.

A typical standard curve is presented in fig 1 . The results of the endogenous vitamin B12 binding capacity of normal human serum and non-immune rabbit serum (table 3 ) show that the B12 binding capacity of the human serum and the non-immune rabbit serum were no longer evident at dilutions of $1 / 1000$ and $1 / 10000$, respectively. The non-specific binding value was $1.4 \%$. As the $\mathrm{R} 4$ antiserum was diluted 1 in 100000 for the assay, no interference from endogenous B12 binding proteins could occur. Human sera (vitamin B12 normal range 111-738 pmol/1) cannot be diluted 1 in 1000 because the concentration of vitamin B12 present in normal serum samples would be below $15 \mathrm{pmol} / \mathrm{l}$, the limit of sensitivity (fig 1 ). Therefore, the endogenous vitamin $\mathrm{B} 12$ binding proteins have to be removed before assay.

Figure 1 Standard curve: percentage $B / B o$ against cyanocobalamin concentration (pmol/l) Abscissa: Cyanocobalamin concentration (pmol ll) antiserum dilution 11 100 000; tracer concentration 22 pmol $/ l$ $N S B=3 \cdot 0 \%$ $B o=42 \cdot 7 \%$. Ordinate: $\% \mathrm{~B} / \mathrm{Bo}$

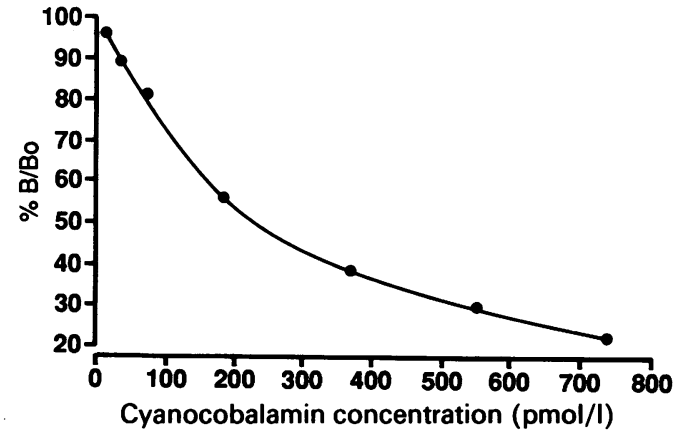

Table 3 Determination of endogenous vitamin B12 binding capacity of normal human serum and non-immune rabbit serum dilutions prepared in buffer using no Tween-20

\begin{tabular}{lll}
\hline & \multicolumn{2}{c}{ Percentage cytano $\left(\mathrm{Co}^{57}\right)$ cobalamin bound } \\
\cline { 2 - 3 } Dilution & Normal human serum & $\begin{array}{l}\text { Non-immune rabbit } \\
\text { serum }\end{array}$ \\
\hline $1 / 10$ & 46.4 & $47 \cdot 9$ \\
$1 / 100$ & $6 \cdot 4$ & $46 \cdot 8$ \\
$1 / 1000$ & 1.8 & 16.5 \\
$1 / 10000$ & 1.4 & $2 \cdot 7$ \\
\hline
\end{tabular}

$\mathrm{NSB}=1 \cdot 4 \%$.

Sixty sera were assayed by RIA and the $L$ leichmannii microbiological assay. The correlation coefficient was 0.85 (fig 2 ). The intrabatch coefficient of variation (CV) of three aliquots of the same serum varied from 12.4 to $20.6 \%$. The interbatch CV was below $22 \%$ with the exception of one serum of very low vitamin B12 content, with a range of $16-49 \mathrm{pmol} / \mathrm{l}$, where the CV was $58.2 \%$ (table 4 ).

Table 5 details the results of recovery of exogenous vitamin B12.

The dicyanide cobinamide and hydroxocobalamin curves were not parallel to the cyanocobalamin curve. The cross-reactivity calculated at $80 \%$ Bo gave 9.8 and $8.1 \%$ for dicyanide cobinamide and hydroxocobalamin, respectively.

\section{Discussion}

Serum vitamin B12 concentrations are currently determined either by RIDAs or microbiological assay. Results obtained using the first generation RIDAs led Kolhouse et $a l^{23}$ and Cooper and Whitehead ${ }^{24}$ to suggest that the non-purified vitamin B12 binding proteins used bound cobalamin analogues which resulted in normal vitamin B12 concentrations being reported for patients with clinical signs of vitamin B12 deficiency. Now, third generation RIDAs, utilising "purified intrinsic factor" or "blocked R-binders", are being produced. Although several RIA methods for the measurement of vitamin $B 12$ have been reported, none is in routine use.

Of the three BSA preparations evaluated, the least expensive gave the best results; the product description was misleading for our

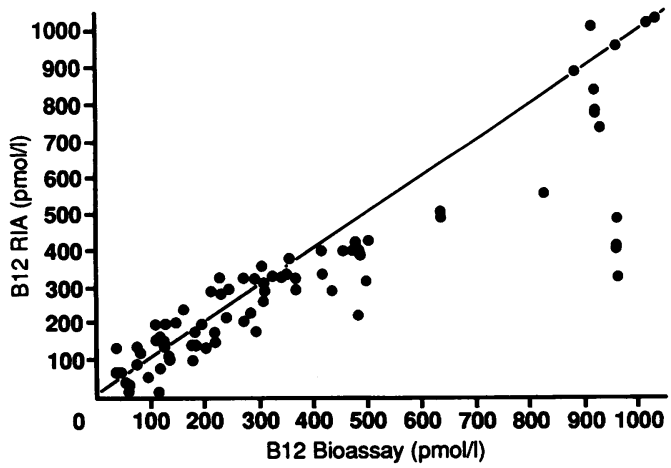

Figure 2 Correlation of vitamin B12 concentrations assayed by $R I A$ and $L$ leichmannii.

Abscissa: B12 bioassay (pmol/l).

Ordinate: B12 RIA (pmol/l). 
Table 4 Intra and Interbatch precision of serum vitamin B12 assay

\begin{tabular}{|c|c|c|c|c|c|}
\hline & Number & $\begin{array}{l}R I A \\
\text { range (pmol/l) }\end{array}$ & Mean (pmol/l) & $C V(\%)$ & $\begin{array}{l}\text { Bioassay } \\
\text { value (pmol/l) }\end{array}$ \\
\hline $\begin{array}{cc}\text { Intrabatch: } \\
\text { Serum } 1 \\
\text { Serum } & 2 \\
\text { Serum } & 3\end{array}$ & $\begin{array}{l}3 \\
3 \\
3\end{array}$ & $\begin{array}{r}93-142 \\
111-142 \\
310-465\end{array}$ & $\begin{array}{l}120 \\
128 \\
384\end{array}$ & $\begin{array}{l}20 \cdot 6 \\
12 \cdot 4 \\
20 \cdot 2\end{array}$ & $\begin{array}{r}148 \\
96 \\
487\end{array}$ \\
\hline $\begin{array}{r}\text { Interbatch: } \\
\text { Serum } 1 \\
2 \\
3 \\
4 \\
5 \\
6 \\
7 \\
8 \\
9 \\
10\end{array}$ & $\begin{array}{l}3 \\
3 \\
3 \\
3 \\
3 \\
3 \\
3 \\
3 \\
3 \\
3\end{array}$ & $\begin{array}{rr}16- & 49 \\
89- & 137 \\
129- & 199 \\
177- & 229 \\
192- & 288 \\
288- & 325 \\
317- & 421 \\
325- & 487 \\
413- & 553 \\
775-1151\end{array}$ & $\begin{array}{r}29 \\
112 \\
168 \\
207 \\
249 \\
311 \\
356 \\
406 \\
485 \\
922\end{array}$ & $\begin{array}{r}58 \cdot 2 \\
21 \cdot 7 \\
21 \cdot 3 \\
12 \cdot 8 \\
20 \cdot 2 \\
6 \cdot 5 \\
15 \cdot 7 \\
20 \cdot 0 \\
14 \cdot 5 \\
20 \cdot 6\end{array}$ & $\begin{array}{r}66 \\
74 \\
199 \\
288 \\
162 \\
369 \\
502 \\
>922 \\
>922 \\
>922\end{array}$ \\
\hline
\end{tabular}

Table 5 Recovery of exogenous vitamin B12 from serum

\begin{tabular}{lll}
\hline $\begin{array}{l}\text { Cyanocobalamin added } \\
\text { (pmolll) }\end{array}$ & $\begin{array}{l}\text { RIA B12 } \\
\text { (pmolll })\end{array}$ & \% Recovery \\
\hline 0 & 251 & \\
74 & 325 & 100 \\
148 & 413 & 109 \\
295 & 561 & 105 \\
590 & 856 & 103 \\
\hline
\end{tabular}

NSB $=2 \cdot 1 \%$.

purposes. Sensitivity, intrabatch, and interbatch CVs in the RIA compared well with those obtained using the $L$ leichmannii assay. The low levels of cross-reactivity indicate that the antibody binding sites recognise the differences in the conformation and electrostatic charges of these cobalamins. Other cobalamins and structurally related molecules have yet to be assessed for cross-reactivity, although all the cobalamins in serum should be converted to cyanocobalamin during the acetate-cyanide serum treatment.

The RIA described can be routinely used for the measurement of vitamin B12 concentrations in serum and lends itself readily to automation, using robotic sampling techniques. Large numbers of assays can be performed per millilitre of antiserum and the assay is much cheaper than commercial kits. There is potential for the development of a non-isotopic immunoassay, alleviating the problem of handling radioactive materials and for the production of monoclonal antibodies.

We thank Mr J Williams, Department of Endocrinology, The Birmingham and Midlands Hospital For Women, who prepared and supplied the magnetisable particles, and Mr D Hayward, Clinical Illustrations Department, Birmingham Denta Hospital

Ross GIM. Vitamin B12 assay in body fluids. Nature 1950; 166:270-1.

2 Mollin DL, Ross GIM. Vitamin B12 assay in body fluids using Euglena gracilis. J Clin Pathol 1952;5:250-6.

3 Hunter SH, Bach MK, Ross GIM. A sugar-containing basal medium for vitamin B12 assay with Euglena: Application to body fluids. J Protozoology 1956;3:101-12.

4 Anderson BB. Investigations into the Euglena method for the assay of vitamin B12 in serum. J Clin Pathol 1964; 17:14-26.

5 Skeggs HR, Huff JW, Wright LD, Bosshardt DK. The use of Lactobacillus leichmannii in the microbiological assay of the "animal protein factor." J Biol Chem 1948;176: $1459-60$.

6 Rosenthal HL, Sarett HP. The determination of vitamin B12 activity in human serum. J Biol Chem 1952;199: 433-42.

7 Spray GH. An improved method for the rapid estimation of vitamin B12 in serum. Clin Sci 1955;14:661-7.

8 Ford JE. The microbiological assay of "vitamin B12." The specificity of the requirement of Ochromonas malhamensis for cyanocobalamin. Br J Nur 1953;7:299-306.

9 Davis BD, Mingioli ES. Mutants of Escherichia coli requiring methionine or vitamin B12. J Bacteriol 1950;60:17-28.

10 Sourial NA. Use of an improved E. coli method for the measurement of cobalamin in serum: Comparison with the measurement of cobalamin in serum: Comparison with the

11 Powell DEB, Thomas JH, Mandal AR, Dignam CT. Effect of drugs on vitamin B12 levels obtained using the Lacto-
bacillus leichmannii method. J Clin Pathol 1969;22:672-6.

2 Matthews DM, Gunasegaram R, Linnell JC. Results with radioisotopic assay of serum $\mathrm{B} 12$ using serum binding agent. J Clin Pathol 1967;20:683-6.

13 Britt RP, Bolton FG, Cull AC, Spray GH. Experience with a simplified method of radio-isotopic assay of serum vitamin B12. Br J Haematol 1969;16:457-64.

14 Rothenberg SP. A radioassay of serum B12 using unsaturated transcobalamin I as the B12 binding protein. Blood 1968;31:44-54.

15 Carmel R, Coltman CA Jr. Radioassay for serum vitamin $\mathrm{B} 12$ with the use of saliva as the vitamin B12 binder. $J$ Lab Clin Med 1969;74:967-75.

16 Green R, Newmark PA, Musso AM, Mollin DL. The use of chicken serum for measurement of serum vitamin B12 concentration by radioisotope dilution: Description of concentration by radioisotope dilution: Description of results. Br J Haematol 1974;27:507-26.

17 Lau K-S, Gottlieb C, Wasserman LR, Herbert V. Measurement of serum vitamin B12 level using radioisotope dilution and coated charcoal. Blood 1965;26:202-14.

18 Liu YK, Sullivan LW. An improved radioisotope dilution assay for serum vitamin B12 using hemoglobin-coated charcoal. Blood 1972;39:426-32.

19 Rothenberg SP. Radio-assay of serum vitamin B12 by quantitating the competition between Co57-B12 and unlabelled B12 for the binding sites of intrinsic factor. J Clin Invest 1963;42:1391-8.

20 Wagstaff $M$, Broughton A. A simple routine radioisotope method for the estimation of serum vitamin B12 using method for the estimation of serum vitamin B12 using Haematol 1971;21:581-93.

21 Muir M, Chanarin I. Solid-phase vitamin B12 assays using polyacrylamide-bound intrinsic factor and polyacrylamide-bound R-binder. $\mathrm{Br} J$ Haematol 1983;53: 423-35.

22 Chanarin I, Muir M. Demonstration of vitamin B12 analogues in human sera not dete:ted by microbiological assay. Br J Haematol 1982;51:171-.3.

23 Kolhouse JF, Kondo H, Allen NC, Podell E, Allen RH. Cobalamin analogues are present in human plasma and can mask cobalamin deficienc' because current radioisotope dilution assays are $n t$ specific for true cobalamin. N Engl J Med 1978;299:735-92.

24 Cooper BA, Whitehead VM. Evidence that some patients with pernicious anaemia are not recognized by radiodilution assay for cobalamin in serum. $N$ Engl $J$ Med dilution assay for

25 Frenkel EP, Kitchens RL, Prough R. High-performance liquid chromatographic separation of cobalamins. liquid chromatographic separatic

26 Binder M, Kolhouse JF, van Horne KC, Allen RH. Highpressure liquid chromatography of cobalamin and cobalamin analogs. Anal Biochem 1982;125:253-8.

27 Gershman H, Nathanson N, Abeles RH, Levine L. Production and specificity of antibodies to $\mathrm{B} 12$ derivatives. Arch Biochem Biophys 1972;153:407-9.

28 van de Wiel DFM, Goedemans WTh, Woldring MG Production and purification of antibody against proteinvitamin $\mathrm{B} 12$ conjugates for radioimmunoassay purposes. Clin Chim Acta 1974;56:143-9.

29 Endres DB, Painter K, Niswender GD. A solid-phase radioimmunoassay for vitamin $B 12$ in serum with use of radioiodinated tyrosine methyl ester of vitamin B12. Clin Chem 1978;24:460-5.

30 Rothenberg SP, Marcoullis GP, Schwarz S, Lader E. Measurement of cyanocobalamin in serum by a specific

31 Quadros EV, Rothenberg SP, Polu S. A specific radioimmunoassay for $5^{\prime}$-deoxyadenosylcobalamin in serum. immunoassay for 5'-deoxyaden

32 Ahrenstedt SS, Thorell JI. The production of antibodies to vitamin B12. Clin Chim Acta 1979;95:419-23. 